\title{
INTEGRATING DNA AND MORPHOLOGICAL TAXONOMY TO DESCRIBE A NEW SPECIES OF THE FAMILY BATHYNELLIDAE (CRUSTACEA, SYNCARIDA) FROM SPAIN
}

\author{
A. I. Camacho*, B. A. Dorda** \& I. Rey ${ }^{* *}$
}

\begin{abstract}
A. I. Camacho, B. A. Dorda \& I. Rey. 2013. Integrated DNA and morphological taxonomy to describe a new species of the Family Bathynellidae (Crustacea, Syncarida) from Spain. Grael/sia, 69(2): 179-200.

A new species of Bathynellidae Grobben, 1905 is described from Spain. Vejdovskybathy-nella vasconica sp. nov. displays an exclusive feature within the genus: eightsegmented antenna. Besides, the new species has a unique combination of morphological characters, including medial seta on exopod of antenna, antennule length similar to antenna, three-segmented mandibular palp without sexual dimorphism, four segments on endopod of thoracopod I to VII, three spines on the sympod of uropod, two claws on the endopod of uropod, first spine longer than the rest on the furcal rami, exopod smaller than endopod on female thoracopod VIII, a long frontal projection and medium size outer protuberance on penial region of male thoracopod VIII, and a medium size frontal crest with a small "spur" on basipod of male thoracopod VIII.

Partial sequences from mitochondrial gene cytochrome oxidase I (COI) and 18S ribosomal RNA (rRNA) gene have been obtained from specimens of the type locality of the new species. The analyses of molecular data demonstrate the presence of two highly divergent genetic units within the Bathynellidae, corresponding to two morphologically well differenciated genera.
\end{abstract}

urn:Isid:zoobank.org:pub:B30D62AD-CE8F-482B-BF4A-8979CD98A31D

Keywords: Syncarida; Bathynellacea; Bathynellidae; Spain; groundwater fauna; new species; morphological data; mtDNA; COI; nuclearDNA; $18 \mathrm{~S}$.

\section{RESUMEN}

A. I. Camacho, B. A. Dorda \& I. Rey. 2013. Integrando ADN y taxonomía morfológica para describir una nueva especie de la familia Bathynellidae (Crustacea, Syncarida) de España. Grael/sia, 69(2): 179-200 (en inglés).

Se describe una nueva especie de la familia Bathynellidae Grobben, 1905 de España. Vejdovskybathynella vasconica sp. nov. presenta un carácter único dentro del género, tener la antena de 8 segmentos. Además la nueva especie exhibe una única combinación de caracteres morfológicos que incluye: seda mediana presente en el exopodio de la antena, anténu-

" Museo Nacional de Ciencias Naturales (CSIC). Dpto. Biodiversidad y Biología Evolutiva. C/ José Gutiérrez Abascal 2. 28006- MADRID (Spain). Corresponding author. Email: mcnac22@mncn.csic.es

** Museo Nacional de Ciencias Naturales (CSIC). Dpto. Colecciones, Colección de Tejidos y ADN. C/ José Gutiérrez Abascal 2. 28006- MADRID (Spain). 
la y antena de igual longitud, palpo mandibular de tres segmentos y sin dimorfismo sexual, cuatro segmentos en el endopodio de todas las patas, tres espinas en el simpodio del urópodo, dos uñas en el endopodio del urópodo, la primera espina de la furca más larga que las demás, toracópodo VIII hembra con exopodio más pequeño que el endopodio, toracópodo VIII macho con una larga prolongación frontal y una protuberancia externa de tamaño medio en la región peneana, así como una cresta frontal de tamaño medio con un pequeño espolón en el basipodio.

Se han obtenido sequencias parciales del gen mitocondrial citocromo oxidasa I (COI) y del gen ribosomal $18 \mathrm{~S}$ ARNr de especímenes de la localidad tipo de la nueva especie. El análisis de estos datos moleculares ha demostrado la presencia de dos unidades genéticas altamente divergentes entre ejemplares de la familia Bathynellidae correspondientes a dos géneros morfológicamente bien diferenciados. La información molecular obtenida en este trabajo complementa la descripción taxonómica tradicional, morfológica, apoyando la validez de la nueva especie perteneciente al género Vejdovskybathynella.

Palabras clave: Syncarida; Bathynellacea; Bathynellidae; Spain; fauna subterránea; nueva especie; morfología; ADNmt; COI; ADN nuclear; $18 \mathrm{~S}$.

\section{Introduction}

In traditional taxonomy a unique combination of morphological features is used to define a given taxon. Nevertheless, this approach does not seem to differentiate some species within certain groups such as the Bathyllenacea, an order of groundwater crustaceans where in some cases morphology is not fully satisfactory to distinguish between closely related species. Therefore, in order to conduct proper taxonomic and evolutionary studies in Bathynellacea it is higly recommended to obtain DNA sequences from different species to establish comparisons, combining a molecular and a morphological approach. This especially holds true for the Bathynellidae, where differences between species are particularly subtle and very difficult to find.

The Family Bathynellidae Grobben, 1905 is widespread in Europe (13 genera and 40 species) but is not well known in the Iberian Peninsula (Camacho, 2006, 2007; Camacho et al., 2013) where only six species in three genera are known: Hispanobathynella catalanensis (Serban, Coineau et Delamare Deboutteville, 1971) (syn.: Meridiobathynella catalanensis Serban, Coineau et Delamare Deboutteville, 1971) from the Ter River Torroella de Montgrí in Catalonia, two species of the genus Paradoxiclamousella (Camacho et al., 2013), and three species of the genus Vejdovskybathynella Serban and Leclerc, 1984 (Camacho, 2007, and Camacho et al., 2013), all from caves in northern Spain. Hispanobathynella and Paradoxiclamousella belong to Tribe Gallobathynellini, subtribe Meridobathynellina Serban, Coineau et Delamare Deboutteville, 1971, and Gallobathynellina, res- pectively; whereas Vejdovskybathynella belongs to Tribe Vejdovskybathynellini Serban, 1989. Some old records mention the presence of the genus Bathynella Vejdovsky, 1882 in Portugal, and even established subspecies for the material found (Noodt \& Galhano, 1969). However, according to Serban (1977) these are probably representatives of the subfamily Gallobathynellinae and not the Bathynellinae, to which the genus Bathynella belongs.

In this paper we describe morphologically a new species of the genus Vejdovskybathynella (Bathynellidae) from the Iberian Peninsula. We obtained sequences of mitochondrial DNA (mtDNA) cytochrome c oxidase I (COI) and of nuclear DNA, $18 \mathrm{~S}$ ribosomal RNA (rRNA) genes, from several specimens of the new species and of representatives of other taxa, some identified down to species level and others not, from the families Bathynellidae and Parabathynellidae. We have compared the divergent clades that can help to assign specimens to genera and to elucidate the phylogenetic relationships between taxa at both higher levels (family and genus) and at the species level.

\section{Material and methods}

\section{Taxonomic Sampling/Specimen Collection}

Specimens studied were found in 4 samples from Goikoetxe cave, Vizcaya (northern Spain). All samples were collected with a $0.1 \mathrm{~mm}$ mesh hand net (plankton type) from water in small gours and pools in the epikarstic zone. The specimens used in the morphological study were fixed in $4 \%$ buffered 
formalin and stored in etanol (70\%). Specimens used for the molecular study were directly frozen at $-20^{\circ} \mathrm{C}$, in $400 \mathrm{ml}$ of distilled water.

The morphological and molecular descriptions are based on the type series.

\section{MORPHOLOGICAL STUDY}

A total of 23 specimens were used in the morphological study: 16 females and seven males collected in 29 April 2011. They constitute the type series of the new species described herein.

A complete dissection of all anatomical parts of several specimens was done and, together with whole specimens, kept as permanent slides (special metal slides, glycerine gelatine stained with Methylene Blue as mounting medium). Anatomical observations were performed using an oil immersion lens (100X) with a Zeiss interference microscope provided with a drawing tube. The material is deposited in the Museo Nacional de Ciencias Naturales, Madrid (MNCN).

We follow the terminology proposed by Serban (1972 and following papers) to name Md and male Th VIII. Serban worked in depth on the family Bathynellidae (Serban 1989a, b, 1992; Serban \& Leclerc, 1984; Serban et al., 1971), revised and described many genera, and we think that his terminology is the most accurate and intuitive.

\section{SPeCimen Collection for DNA EXTRACTION}

Twenty eight specimens were used for DNA extraction, but succesful DNA extraction was only posible from six, and are part of the type series.

This type material, the DNA extracted from the six specimens, is deposited in the Tissues and DNA Collection of the Museo Nacional de Ciencias Naturales, Madrid (MNCN). Voucher numbers are shown in Table 1.

In order to examine the phylogenetic relationships between bathynellids, we used partial DNA sequences of the mtDNA gene COI (508 bp) and the nuclear 18S rRNA (997 bp). The small subunit (SSU) 18S rRNA gene is one of the most frequently used genes in phylogenetic studies and an important marker for random target PCR in environmental biodiversity screening (Chenuil, 2006) and in general, rRNA gene sequences are easy to access due to their highly conserved flanking regions allowing the use of universal primers (Hillis \& Dixon, 1991). COI sequences were obtained from two individuals, and 18S rRNA sequences were obtained from six specimens.
DNA Extraction, Amplification, AND SEQUENCING Extraction was carried out with Chelex following Walsh et al. (1991). Fresh specimens were cut in two in distilled water, and were placed in the wall of a $1.5 \mathrm{ml}$ microcentrifuge tube with a sterile needle. Each tube contained $100 \mathrm{ml}$ Chelex 100 (Bio-Rad; 5\% in distilled water) and $400 \mathrm{ml}$ of distilled water. The specimens were incubated overnight at $56^{\circ} \mathrm{C}$, followed by 10 minutes at $100^{\circ} \mathrm{C}$ and centrifuged at $16,000 \mathrm{~g}$ for 10 minutes.

A 510 base pair (bp) region of the COI gene was amplified with the primers C1-J-1718 (5'-GGAGGATTTGGAAATTGATTAGTTCC-3') and HCO2198 (5'-TAAACTTCAGGGTGACCAAAA AATCA-3') (Folmer et al., 1994; Simon et al., 1994). A 997 base pair (bp) fragment of the $18 \mathrm{~S}$ rRNA region was amplified in two fragments, using the primers $1 \mathrm{~F}$ (5'-TACCTGGTTGATCCTGCCAG TAG-3') and 3R (5'-AGGCTCCCTCTCCGGAATCGAAC-3') and 3F (5'-GTTCGATTCC GGAGAGGGA-3') (Giribet et al., 1996) and bi (5'-GAGTCTCGTTCGTTATCGGA-3') (Whiting et al., 2002). Three $\mathrm{ml}$ of the DNA solution were used as a template. Other components of the $25 \mathrm{ml}$ PCR reaction were: $1 \mathrm{x}$ of the corresponding buffer (75 mM Tris HCl, pH 9.0; $50 \mathrm{mM} \mathrm{KCl}$ and $20 \mathrm{mM}$ $\left.\left(\mathrm{NH}_{4}\right)_{2} \mathrm{SO}_{4}\right), 2 \mathrm{mM} \mathrm{MgCl}$ ), $10 \mathrm{mM}$ dNTPs mix, 0.1 $\mathrm{mM}$ of both primers, $0.02 \%$ BSA, and 0.125 units AmpliTaq Gold ${ }^{\circledR}$ DNA Polymerase (Applied Biosystems). Six ml of PCR products were electrophoresed through a $1.5 \%$ agarose gel and visualized with Ethidium Bromide under ultraviolet light. PCR products were purified by treatment with ExoSAP-IT (USB Amersham, Buckinghamshire, UK) in a 5:1 amplicon: enzyme ratio and incubated at $37^{\circ} \mathrm{C}$ for $45 \mathrm{~min}$, followed by $15 \mathrm{~min}$ at $80{ }^{\circ} \mathrm{C}$ to inactivate the enzyme. The purified PCR product was then used to sequence in both directions using the BigDye Terminator v3.1 sequencing kit (Applied Biosystems Inc., Foster City, USA) in a 10 IL volume, containing $15-20 \mathrm{ng}$ of purified product and 3 pmol of primer. To verify that the sequences obtained came from a bathynellacean, they were compared with sequences from GenBank using Blast (Altschul et al., 1997). The alignment of all bathynellacean COI and $18 \mathrm{~S}$ gene sequences generated in our lab was performed and edited manually using MEGA 4.0 (Tamura et al., 2007). Fine adjustments were made by eye, as the COI does not present any gaps. All sequences were submitted to GenBank (see Table 1 for collection 


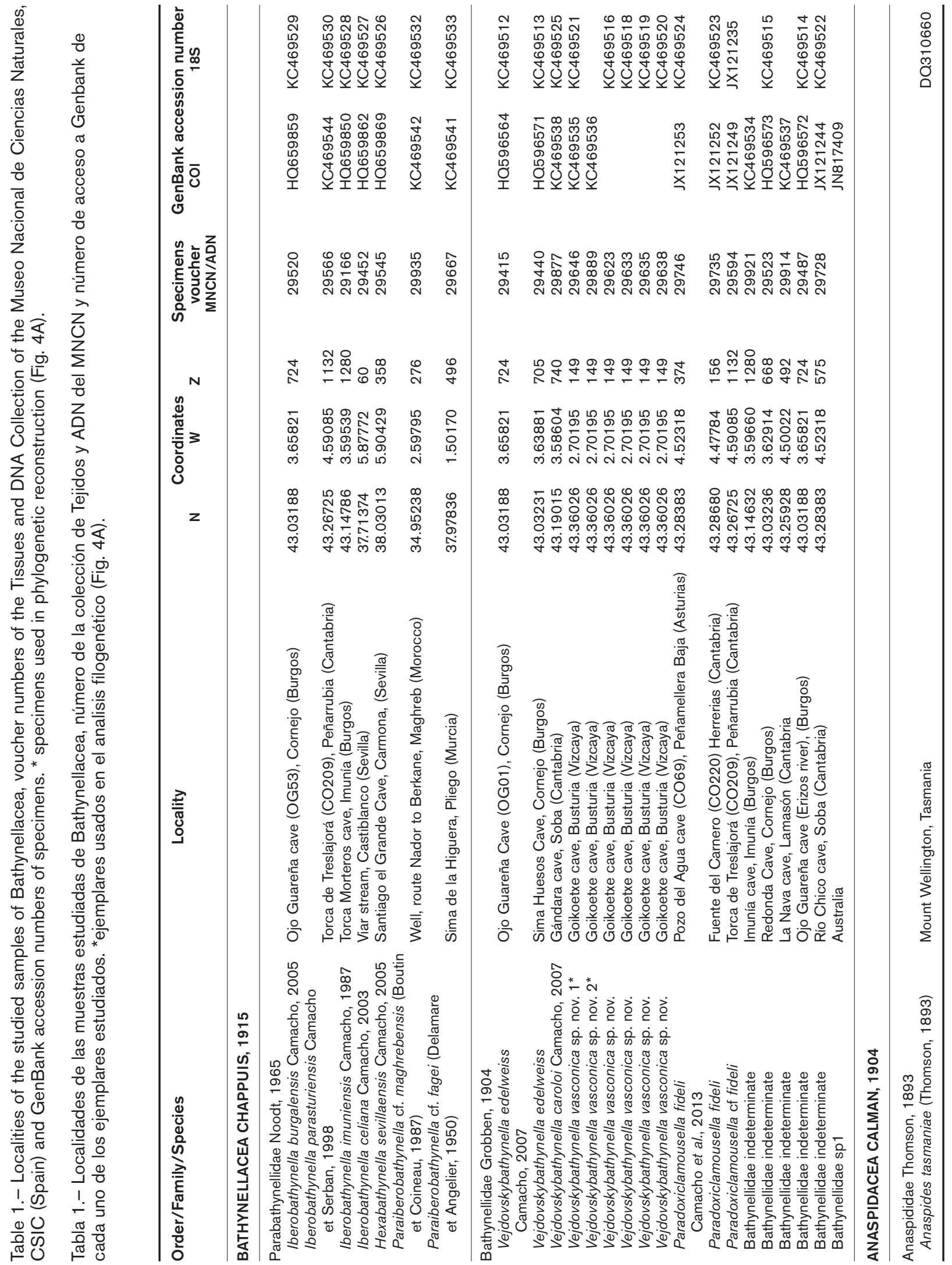

Graellsia, 69(2), Diciembre 2013, pp. 179-200 - ISSN: 0367-5041

doi:10.3989/graellsia.2013.v69.086 
Table 2.- COI genetic distances among and within species groups of the Spanish and Australian Bathynellidae.

Tabla 2.- Distancia genética encontrada en el gen COI entre y dentro de grupos de especies de la familia Bathynellidae de España y Australia.

\begin{tabular}{|c|c|c|c|c|c|c|c|c|c|c|c|c|c|c|c|}
\hline & 1 & 2 & 3 & 4 & 5 & 6 & 7 & 8 & 9 & 10 & 11 & 12 & 13 & 14 & 15 \\
\hline 1 Bathynellidae Erizos & 0 & & & & & & & & & & & & & & \\
\hline 2 Bathynellidae Chico & 2.56 & 0 & & & & & & & & & & & & & \\
\hline $3 \mathrm{~V}$. edelweiss $1 \mathrm{OG} 01$ & 14.57 & 14.96 & 0 & & & & & & & & & & & & \\
\hline $4 \mathrm{~V}$. edelweiss Huesos & 14.76 & 14.76 & 1.57 & 0 & & & & & & & & & & & \\
\hline 5 Bathynellidae Imunia & 14.57 & 14.96 & 13.39 & 12.99 & 0 & & & & & & & & & & \\
\hline 6 Bathynellidae Redonda & 16.93 & 16.93 & 15.16 & 14.37 & 6.10 & 0 & & & & & & & & & \\
\hline \multicolumn{16}{|l|}{7 V. vasconica sp. nov. } \\
\hline Goiko & 12.99 & 13.39 & 14.17 & 14.17 & 12.80 & 14.76 & 0 & & & & & & & & \\
\hline \multicolumn{16}{|l|}{$8 \mathrm{~V}$. vasconica sp. nov. } \\
\hline Goiko & 13.19 & 13.58 & 14.76 & 14.76 & 13.39 & 15.35 & 0.59 & 0 & & & & & & & \\
\hline 9 Bathynellidae Nava & 15.75 & 15.55 & 16.73 & 16.73 & 16.34 & 17.72 & 16.14 & 16.34 & 0 & & & & & & \\
\hline 10 P. cf. fideli CO209 & 16.54 & 16.54 & 17.91 & 18.11 & 16.14 & 18.31 & 16.73 & 16.73 & 10.63 & 0 & & & & & \\
\hline 11 P. fideli CO69 & 17.13 & 17.72 & 18.31 & 17.91 & 15.35 & 17.91 & 15.75 & 15.95 & 11.22 & 7.30 & 0 & & & & \\
\hline 12 P. fideli Carnero & 16.73 & 17.32 & 17.91 & 17.52 & 14.96 & 17.52 & 15.75 & 15.95 & 10.83 & 6.89 & 0.39 & 0 & & & \\
\hline 13 V. caroloi Gándara & 17.52 & 17.72 & 19.68 & 18.90 & 17.72 & 18.31 & 16.53 & 16.73 & 16.92 & 19.45 & 17.91 & 17.52 & 0 & & \\
\hline 14 Bathynellidae sp1 Australia & 21.85 & 21.85 & 21.65 & 20.87 & 17.72 & 19.68 & 18.70 & 19.29 & 19.29 & 19.68 & 19.29 & 19.29 & 21.46 & 0 & \\
\hline 15 I. imuniensis Morteros & 25.20 & 25.20 & 22.64 & 22.05 & 22.05 & 23.43 & 22.64 & 23.03 & 23.23 & 22.64 & 23.03 & 23.03 & 23.43 & 22.83 & 0 \\
\hline
\end{tabular}

voucher numbers of each specimen and the GenBank Accession Number).

\section{Phylogenetic And DNA Sequence Analysis}

Phylogenetic reconstruction based on COI and $18 \mathrm{~S}$ rRNA sequence data involved Bayesian Inference (BI), maximum likelihood (ML) and maximum parsimony (MP) approaches, using separate data sets. To examine relationships between species of Bathynellidae, we analysed the mtDNA COI sequences obtained by us from several species of Vejdovskybathynella Serban et Leclerc, 1984 (V. edelweiss Camacho, 2007 and V. caroloi Camacho, 2007), Paradoxiclamousella Camacho, Dorda et Rey, 2013 (P. fideli Camacho, Dorda et Rey, 2013 and $P$. cf fideli) and other undetermined genera from Spain. The Parabathynellid Iberobathynella imuniensis from Spain was chosen as out-group (GenBank accession number HQ659850). To examine relationships between families and genera, we used $18 \mathrm{~S}$ rRNA sequences obtained by us. Genera of Parabathynellidae included Iberobathynella Schminke, 1973, Paraiberobathynella Camacho et Serban, 1998 and Hexabathynella Schminke, 1972, all from Spain. In the case of the Bathynellidae, we used the genera Vejdovskybathynella, Paradoxiclamousella, plus other not yet determined material from Spain (voucher and
GenBank accession numbers shown in Table 1). The Anaspidid Syncarida Anaspides tasmaniae Thomson, 1893 was chosen as out-group (GenBank accession number DQ310660). Pairwise comparisons of observed proportional sequence divergence (p-distance) (Tables 2 and 3) and corrected sequence divergence (Kimura-2parameter model), were determined using PAUP*4.0b10 (Swofford, 2002). To test for possible saturation of nucleotide substitutions (only with COI sequences), we plotted p-distance (y) versus corrected estimates of proportional sequence divergence $(\mathrm{x})$ for first, second and third codon positions, as well as for transitions and transversions separately (not shown). We initially explored the dataset using distance analyses (neighbour joining, NJ) with PAUP*4.0b10. Phylogenetic analyses were conducted using Maximum Likelihood (ML; Felsenstein, 1981, 1985) and Bayesian inference (BI) (Huelsenbeck \& Ronquist, 2001; Ronquist \& Huelsenbeck, 2003). All characters were equally weighted. Modeltest 3.7 (Posada \& Crandall, 1998) were used to identify the model of sequence evolution that best fit the data, based on Akaike information criteria (AIC), for use in the phylogenetic (ML) and distance analyses (NJ). The general timereversible model of evolution (GTR) with gamma parameter and a proportion of invariable positions 
Table 3.- $18 \mathrm{~S}$ genetic distances among and within species groups of the Spanish Bathynellacea.

Tabla 3.- Distancia génetica en el gen $18 \mathrm{~S}$ entre y dentro de grupos de especies españolas de la familia Bathynellidae.

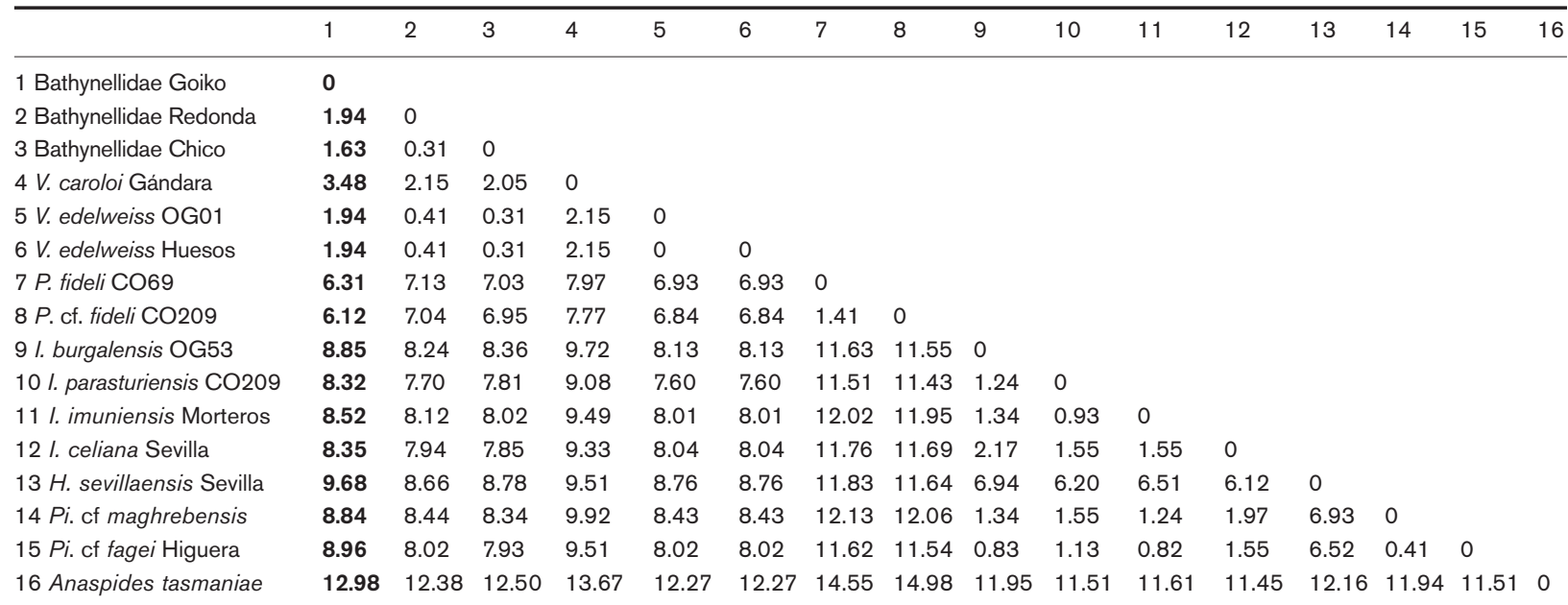

$(\mathrm{GTR}+\mathrm{G}+\mathrm{I})$ was selected as the best fit and was used for ML (Yang, 1994; Gu et al., 1995; Swofford et al., 1996) and BI analyses. ML analyses with empirical base frequencies were performed using Garli (Zwickl, 2006; Zwickl \& Balhoff, 2006). We used nonparametric bootstrapping (500 pseudoreplicates) to assess the stability of internal branches in the resulting topologies (Felsenstein, 1985; Felsenstein \& Kishino, 1993). BI analysis was performed with MrBayes 3.1.2 (Ronquist \& Huelsenbeck, 2003) assuming six discrete gamma categories. Bayesian analyses were initiated with random starting trees and run for 1,000,000 generations sampled every 100 generations. The convergence occurred during the first million generations, the likelihood values converged to relative stability after approximately 100,000 generations; subsequently we conservatively discarded all samples obtained during the first hundred thousand (10\%) generations as burnin. Robustness of the observed clades was assessed with Bayesian posterior probabilities.

\section{Systematic account}

According to Serban (2000), it was assumed that the largest part of France and the Iberian Peninsula is populated by representatives of the subfamily Gallobathynellinae Serban et al., 1971. This subfamily consists of four tribes (the differences are shown in Table 4), two subtribes, 11 genera, and 25 species including the new species described herein (Camacho, 2007; Camacho et al., 2013). The majority of the species occur in France, two are known from Italy, one from Switzerland, one from Germany, and eight, including the new species, from Spain.

The new species belongs to the Tribe Vejdovskybathynellini Serban, 1989 (see Table 4) based on the number of main teeth on the Mandible (5), the three-segmented mandibular palp, the four segmented endopod of the thoracopods I to VII, an antennule similar in size to antenna, basipod of the male thoracopod VIII vertical and with frontal crest with frontal spur and penial region with a lobe with outer protuberance, a developed frontal projection and one outer lobe of similar length. This Tribe has a single genus, Vejdovskybathynella Serban et Leclerc, 1984, to which the new species belongs. Table 5 summarizes the main features of the different genera from subtribes Gallobathynellina and Meridiobathynellina, as well as the genus Vejdovskybathynella, clearly identifying the differences between them. 
Table 4.- Differences amongst the tribes of the Subfamily Gallobathynellinae Serban, Coineau et Delamare Debutteville, 1971: Gallobathynellini Serban, Coineau et Delamare Debutteville, 1971; Pseudobathynellini Serban, 1989; Sardobathynellini Serban, 1992 and Vejdovskybathynellini Serban, 1989. (Modified from Serban 1989). Terminology of the Thoracopod VIII male translated from the terminology used by Serban: région pénienne= penial region; lobe $=$ lobe $(\mathrm{lb})$; prolongement rostral= frontal projection (fr. pj.); lobule interne= inner lobe (I.lb); lobule externe= outer lobe (O.lb); proéminence externe $=$ outer protuberance (O. prt.).

Tabla 4.- Diferencias entre las tribus de la subfamilia Gallobathynellinae Serban, Coineau et Delamare Debutteville, 1971: Gallobathynellini Serban, Coineau et Delamare Debutteville, 1971; Pseudobathynellini Serban, 1989; Sardobathynellini Serban, 1992 y Vejdovskybathynellini Serban, 1989. (Modificado de Serban 1989). La terminología usada para el Th VIII macho está traducida de la terminología empleada por Serban: région pénienne= región peneana; lobe $=$ lóbulo (lb); prolongement rostral= proyección frontal (fr. pj.); lobule interne= lóbulo interno (I.lb); lobule externe= lóbulo externo (O.lb); proéminence externe= prominencia externa (O. prt.).

\begin{tabular}{|c|c|c|c|c|}
\hline & Gallobathynellini & Pseudobathynellini & Sardobathynellini & Vejdovskybathynellini \\
\hline A.I: number of segments & $6 / 7$ & 7 & 7 & 7 \\
\hline A.Il: endopod & $6-7-8$ & 8 & 7 & $7 / 8$ \\
\hline Medial seta of exopod & present/absent & present & present & present \\
\hline A.I/A.II & A.I=A.II/A.I $>$ A.II/A.I<A.II & A.I $>$ A.II & A.I $>$ A.II & A.I=A.II \\
\hline Md: $n^{\circ}$ of principal teeth & $5-6$ & 7 teeth & 7 teeth & $5-6$ teeth \\
\hline Segments on palp & $1-3$ & 3 & 3 & 3 \\
\hline Sexual dimorfism on palp & not & yes & yes & yes/not \\
\hline \multirow[t]{4}{*}{ Th. 1 to $7:$ endopod } & $4 / 4 / 4 / 4 / 4 / 4 / 4$ & $4 / 4 / 4 / 4 / 4 / 4 / 4$ & $4 / 4 / 4 / 4 / 4 / 3 / 3$ & $4 / 4 / 4 / 4 / 4 / 4 / 4$ \\
\hline & $4 / 3 / 3 / 3 / 3 / 4 / 4$ & & & \\
\hline & $4 / 3 / 3 / 3 / 3 / 3 / 3$ & & & \\
\hline & $3 / 3 / 3 / 3 / 3 / 4 / 4$ & & & \\
\hline Th 8 male: type & Gallobathynella & Pseudobathynella & Pseudobathynella & Vejdovskybathynella \\
\hline Penial region & Lb+F.prj+O.lb/or not & Lb+l.Lb+small O.lb & I.Lb+small O.lb & lobe+F. prj+ big O.lb \\
\hline outer protuberance (O.prt) & on Bsp & on Bsp/on coxopod & included on coxopod & included on coxopod \\
\hline Basipod (Bsp) & inclined $35^{\circ}$ & inclined $30^{\circ}$ & inclined $30^{\circ}$ & vertical \\
\hline Th 8 female: coxal seta & long & short & short & long/absent \\
\hline epipod & present (big)/absent & present (big) & present (big) & present (big) \\
\hline endopod/exopod size & endopod<exopod & endopod=exopod & endopod=exopod & endopod $<=>$ /exopod \\
\hline Uropod: sympod & 3-4 spines & 3-4 spines & 3 spines & 3-4 spines \\
\hline Endopod & $2-3$ claws & $2-3$ claws & 4 claws & $2-3$ claws \\
\hline Furca: spines & similar/different & different & similar & similar/different \\
\hline
\end{tabular}

Tribe Vejdovskybathynellini Serban, 1989

DiAGNOSIS (translated from Serban 1989a, 1989b and modified)

A. I and A. II ordinary. Md.: mandibular palp with three segments with the setae longer in the males than in the females or not. Th. I-VII: endopod with four segments in all the pairs. Male Th. VIII: penial region with one lobe that shows an elongated frontal projection and an outer lobe, vertical basipod with a very prominent frontal crest (Fr. crt.) and with a distal region curved on the external side, forming a spur ("eperon") (S. fr. crt.); endopod a single segment, elongated and shorter than the exopod. Female Th. VIII ordinary, coxal seta elongated or absent (see Table 4).
Genus Vejdovskybathynella Serban et Leclerc, 1984

DiAgnosis (modified from Serban and Leclerc 1984 and Camacho, 2007)

A. I: with seven segments. Md.: mandibular palp with or without sexual dimorphism. Male Th. VIII: penial region with frontal projection and a large outer lobe; the basipod has a vertical position and a prominent frontal crest (Fr. crt.). Female Th. VIII: with an exopod simplified. Uropod: sympod with three or four spines and endopod with two or three spines. Furcal rami: first or second spine the longest (see Table 5).

TYPE SPECIES. Vejdovskybathynella balazuci Serban et Leclerc, 1984. 

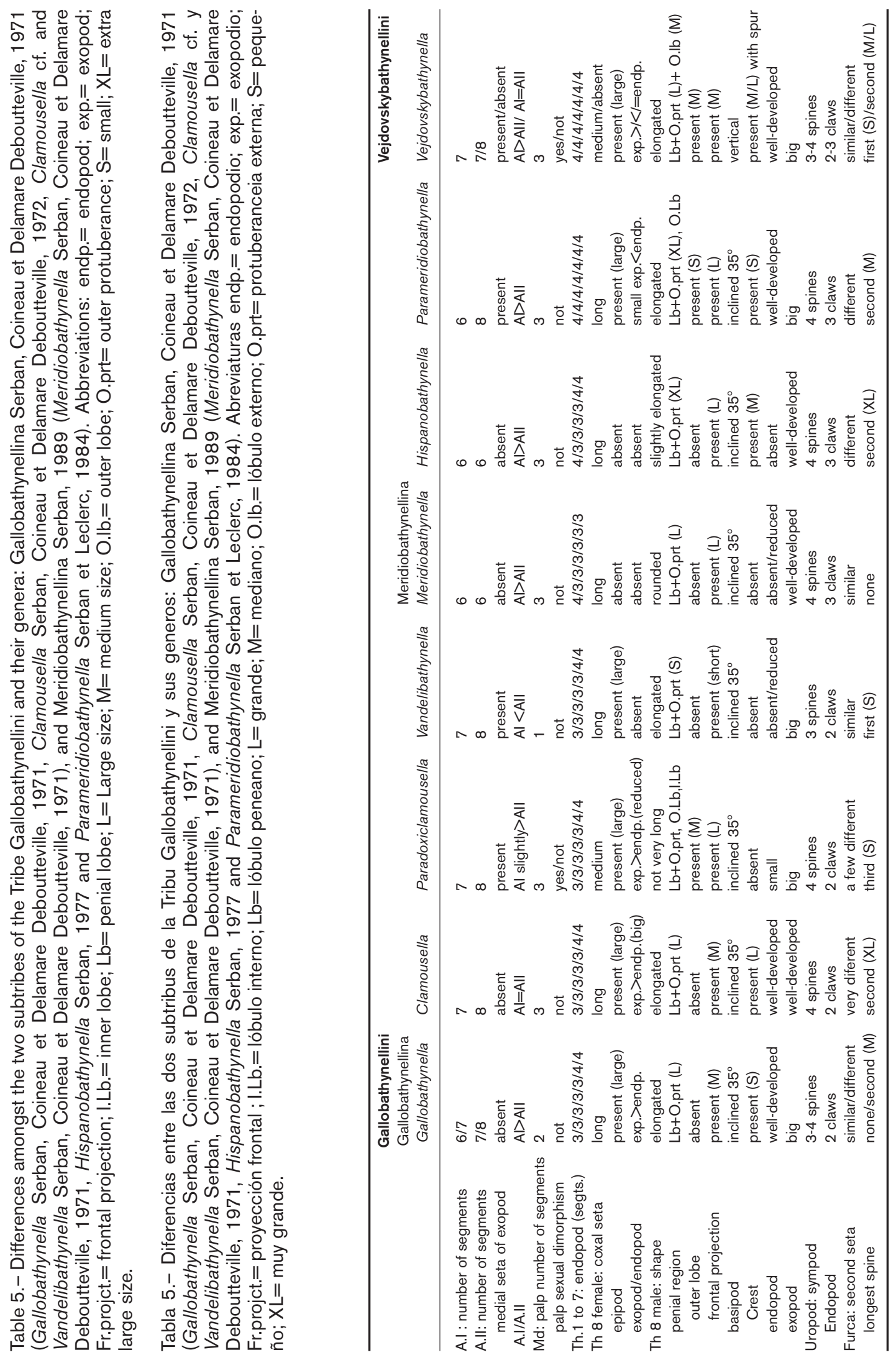

Graellsia, 69(2), Diciembre 2013, pp. 179-200 - ISSN: 0367-5041

doi:10.3989/graellsia.2013.v69.086 


\section{Vejdovskybathynella vasconica sp. nov.}

(Figs. 1-3)

Material EXAMINed

Type locality. Goikoetxe Cave, Busturia (Vizcaya, Spain); coordinates N 43.36703, W 2.70195 and Z: 3149 (WGS84); 29 April 2011 (69 specimens collected, six of them juveniles).

Type series comprises Holotype male of $0.79 \mathrm{~mm}$ (MNCN 20.04/9119), allotype female of $0.66 \mathrm{~mm}$ (MNCN 20.04/9120), 6 males and 15 females paratypes (MNCN 20.04/9121 to 9141) and 6 DNAtypes (MNCN/ADN: 29646; 29889; 29623; 29633; 29635 and 29638).

\section{DESCRIPTION}

Body. Total length of males $0.65-0.79 \mathrm{~mm}$, of females 0.56-0.85 mm. Body elongated, segments slightly widening towards posterior end; each approximately nine times as long as wide. Head twice as long as wide. Pleotelson with one small smooth dorsal seta at each side. All drawings are of the holotype (male) except for Th VIII female, and one figure of $\mathrm{Md}$ that belongs to the allotype.

Antennule (Fig. 1A). As long as antenna, sevensegmented; length of first three segments slightly longer than the other four segments; fourth and sixth segmentssimilar and smaller than seventh; fifth smallest; inner flagellum rectangular; setation as in Fig. 1A; segment six and seven with two terminal aesthetascs, all similar in size.

Antenna (Fig. 1B). Eight-segmented; as long as antennule; distal and fifth segment longer than rest, terminal longest; last four segments twice as long as the first four; ventromedial seta of exopod present, and two apical setae, one of them a bifurcated sensory seta; setal formula: $0 / 0 / 2+\exp / 2+0 / 1+0 /$ $0+0 / 2+2 / 4$.

Labrum (Fig. 1C). Almost triangular and smooth.

Paragnaths (Fig. 1D). Elongated and with a projection on the distal part; with fine setules around distal part.

Mandible (Figs. 1E, F). Palp with three segments, terminal segment with two equal and barbed claws. Masticatory part: pars molaris with five simple main teeth, processus incisivus accessorius with one tooth and incisor process (pars incisiva) with two teeth.

Maxillule (Fig. 1G). Proximal endite with four setae; distal endite with six teeth, four of which provided with denticles othertwo simple, seta-like; three plumose setae, of similar size, on the outer margin of endite.

Maxilla (Fig. 1H). Four-segmented; setal formula $6,4,6,4$.
Thoracopods I-VII (Figs. 2A, E and 3A, B). Th I (Fig. 2A) smaller than rest; Th II (Fig. 2B) to V (Fig. 2E) similar in size, Th VI (Fig. 3A) to VII (Fig. 3B) longer than rest. Th I without epipod; coxa with a long strong plumose seta; basipod with two barbed setae. Basipod of Th II and Th III with two smooth setae; one smooth seta on basipod of rest of thoracopods. Exopod one-segmented in all thoracopods, similar in size to the endopod in Th I to Th V, and half lenght ofendopod in Ths VI and VII; exopods with five barbed setae, with groups of ctenidia at base of setae. Endopod with four segments in all thoracopods; all setae smooth except those on distal outer corner of segment two, that is plumose; groups of ctenidia at lateral internal edge of endopod in all segments. Thoracopod endopod setal formulae: Th I, $3+0 / 3+1 / 3+0 / 4$; Th II: $2+0 / 2+1 / 1+0 / 4$; Th III: $1+0 / 2+1 / 2+0 / 4$; Th IV: $0+0 / 1+1 / 1+0 / 4$; Th V: $0+0 / 0+1 / 1+0 / 3$; Th VI: $0+0 / 0+1 / 0+0 / 2(1)$; Th VII: $0+0 / 0+1 / 0+0 / 2(1)$.

Male thoracopod VIII (Fig. 3C, D). Outer lobe (O. lb.), similar to the frontal projection and not exceeding the basipod, both with transverse circular section; expanded outer protuberance (O. prt.); vertical rectangular basipod (Bsp.) without seta; frontal crest of basipod not very prominent and with a very small spur; exopod with six setae; endopod one-half the size of the exopod, with two small terminal setae of similar length.

Female thoracopod VIII (Fig. 3E). Coxa without setae; very large epipod reaching, beyond distal end of exopod; endopod small and slightly more slender than exopod, single segment with two apical smooth setae; exopod with two apical unequal smooth setae of different lengths.

First pleopod (Fig. 3F). Two-segmented, first segment with one seta; second segment with four setae, all smooth.

Uropod (Fig. 3G). Sympod 1.6 times longer than wide and 1.6 times longer than endopod, with three equal spines; endopod slightly longer than exopod, with two strong similar claws, terminally with two barbed setae (one of them very long) and with two plumose setae located dorsolaterally; exopod with two barbed terminal setae, of which external very long and two small barbed medial setae.

Pleotelson (Fig. 3H). With one short, smooth dorsal seta at either side near base of furca.

Furcal rami (Fig. 3H). Almost square, bearing five spines; dorsal spine a little shorter than second 


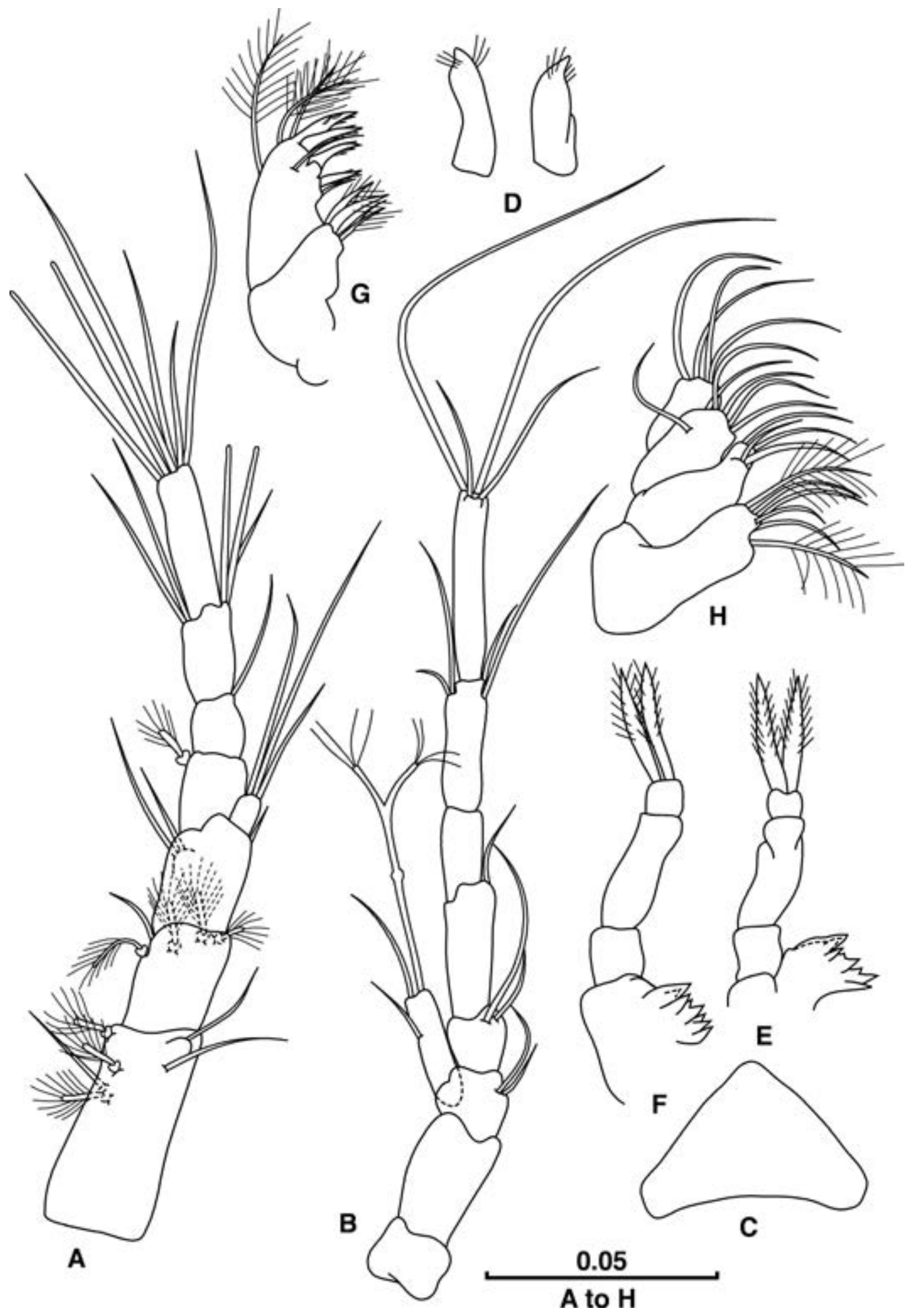

Fig. 1.- Vejdovskybathynella vasconica sp. nov., male holotype. (A) Antennule (dorsal view); (B) Antenna (dorsal view); (C) Labrum; (D) Paragnaths; (E) Mandible; (F) female Mandible; (G) Maxillule; (H) Maxilla. Scale bar in mm.

Fig. 1.- Vejdovskybathynella vasconica sp. nov., holotipo macho. (A) Anténula (vista dorsal); (B) Antena (vista dorsal); (C) Labro; (D) Paragnatos; (E) Mandíbula; (F) Mandíbula de la hembrae; (G) Maxílula; (H) Maxila. escala en mm. 


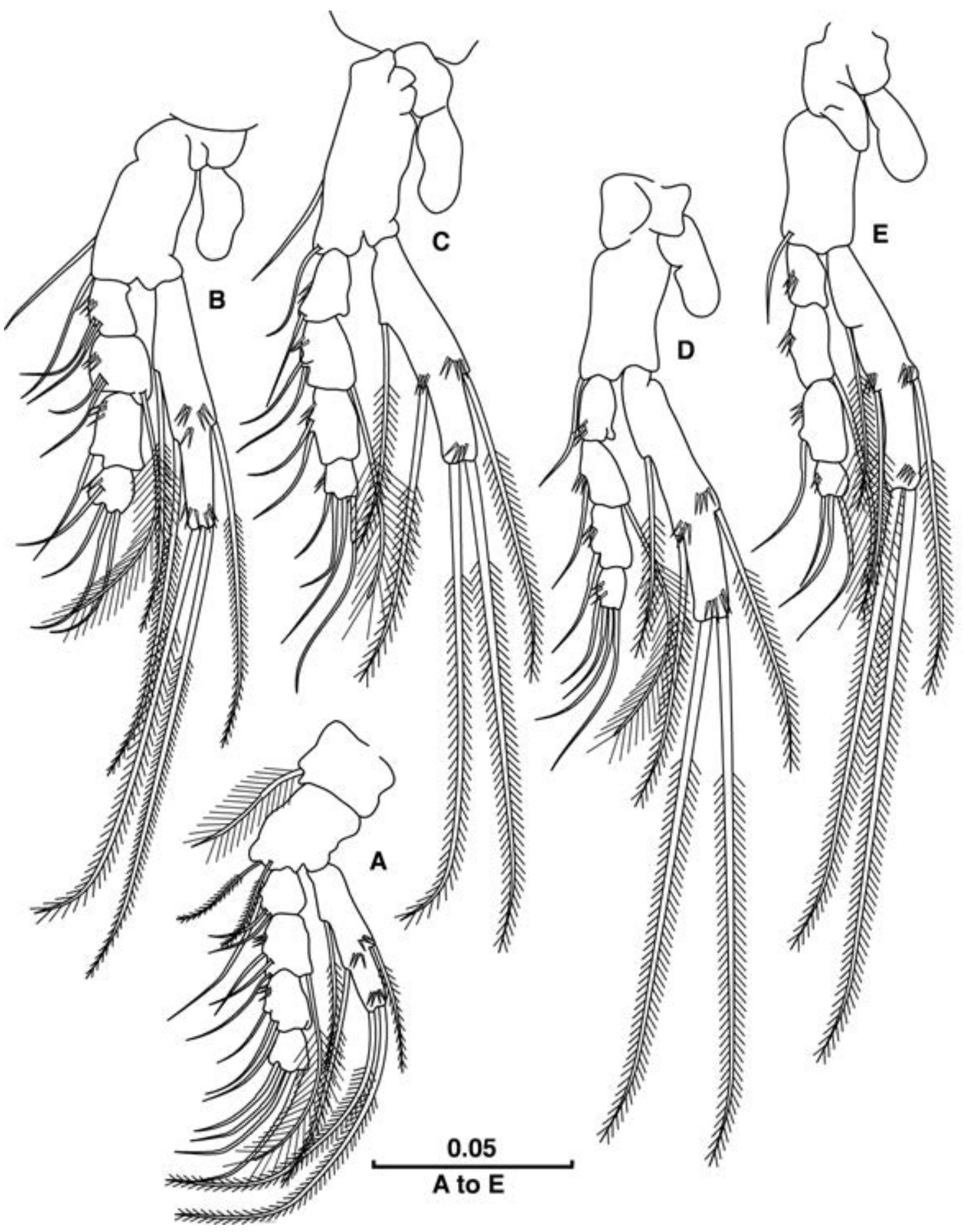

Fig. 2.- Vejdovskybathynella vasconica sp. nov., male holotype. (A) Thoracopod I; (B) thoracopod II; (C) thoracopod III; (D) thoracopod IV; (E) thoracopod V. Scale bar in $\mathrm{mm}$.

Fig. 2.- Vejdovskybathynella vasconica sp. nov., holotipo macho. (A) Toracópodo I; (B) toracópodo II; (C) toracópodo III; (D) toracópodo IV; (E) toracópodo V. Escala en mm. 


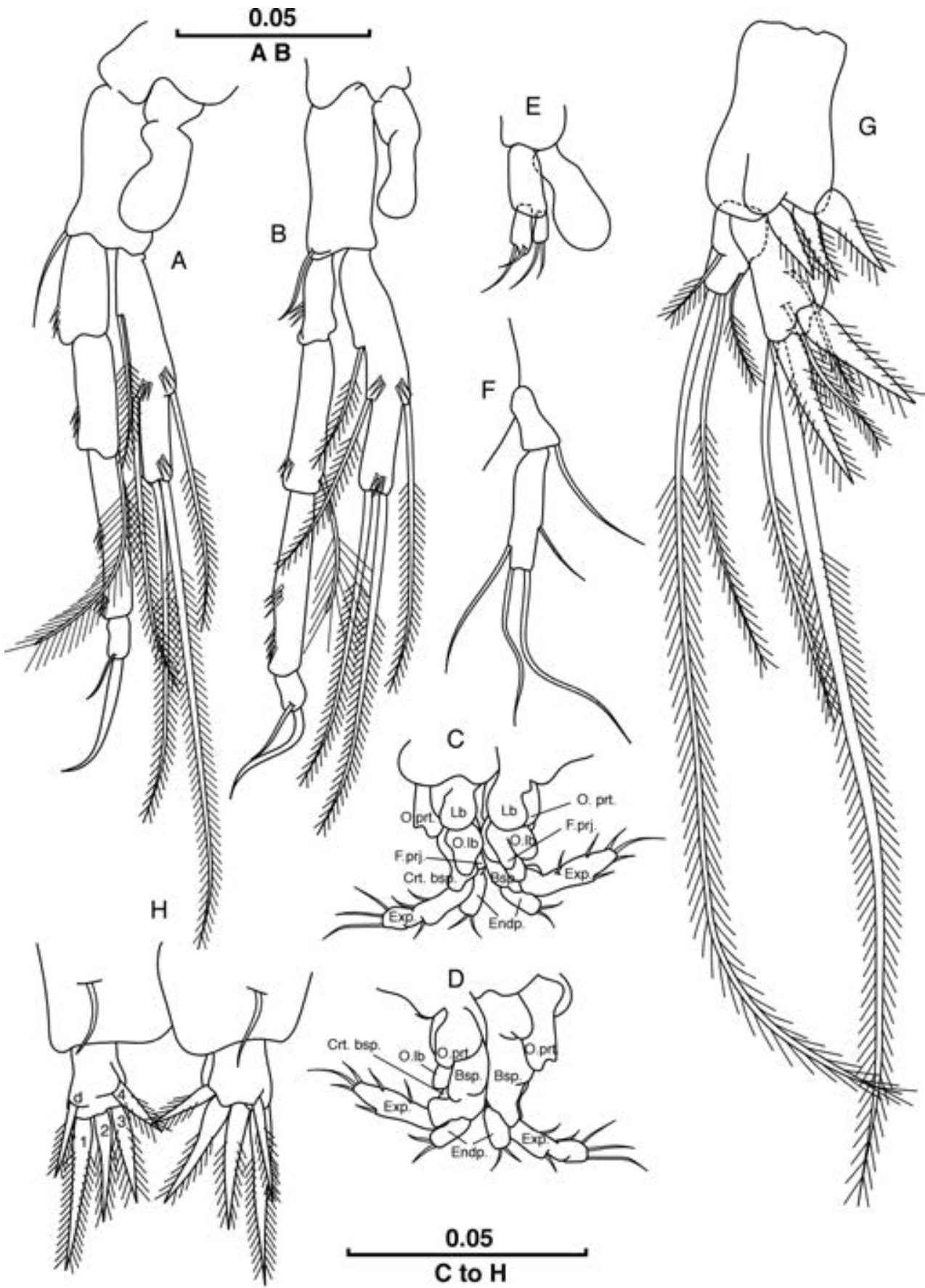

Fig 3.- Vejdovskybathynella vasconica sp. nov., male holotype. (A) thoracopod VI; (B) thoracopod VII; (C) thoracopod VIII (frontal view); (D) thoracopod VIII (ventral view); (E) female thoracopod VIII (frontal view); (F) pleopod (frontal view); (G) uropod (latero-external view); (H) furcal rami (dorsal view). Scale bar in mm. Abbreviations: Bsp, basipod; Crt. bsp., crest of basipod; d., dorsal spine; Endp, endopod; Exp, exopod; Fr. prj., frontal projection; O. prt., outer protuberance; O. Lb, outer lobe.

Fig 3.- Vejdovskybathynella vasconica sp. nov., holotipo macho. (A) toracópodo VI; (B) toracópodo VII; (C) toracópodo VIII (vista frontal); (D) toracópodo VIII (vista ventral); (E) toracópodo VIII de la hembra (vista frontal); (F) pleópodo (vista frontal); (G) urópodo (vista latero-externa); (H) ramas furcales (vista dorsal). Escala en mm. Abreviaturas: Bsp, basipodio; Crt. bsp., cresta del basipodio; d., espina dorsal; Endp, endopodio; Exp, exopodio; Fr. prj., projección frontal; O. prt., protuberancia externa; O. Lb, lóbulo externo. 
Table 6.- Differences amongst the six species known of the genus Vejdovskybathynella Serban \& Leclerc, 1984. 1.Vejdovskybathynella balazuci Serban \& Leclerc, 1984 (France); 2.- V. espattyensis Serban \& Leclerc, 1984 (France); 3.V. leclerci Serban, 1989 (France); 4.- V. edelweiss (Spain); 5.- V. caroloi (Spain); 6.- V. pascalis (Spain) and 7.- V. vasconica sp. nov. (Spain). A.I= antennule; A.II= Antenna; Plp= pleopod; exp.= exopod; endp.= endopod; segs.= segments; $\mathrm{P}=$ present; $A=$ absent

Tabla 6.- Diferencias entre las seis especies conocidas del género Vejdovskybathynella Serban \& Leclerc, 1984. 1.Vejdovskybathynella balazuci Serban \& Leclerc, 1984 (Francia); 2.- V. espattyensis Serban \& Leclerc, 1984 (Francia); 3.V. leclerci Serban, 1989 (Francia); 4.- V. edelweiss (España); 5.- V. caroloi (España); 6.- V. pascalis (España) y 7.- V. vasconica sp. nov. (España). A.I= anténula; $A . I I=$ Antena; $P l p=$ pleópodo; exp.= exopodito; endp.= endopodito; segs.= segmentos; $\mathrm{P}=$ presente; $\mathrm{A}=$ ausente.

\begin{tabular}{|c|c|c|c|c|c|c|c|}
\hline & 1 & 2 & 3 & 4 & 5 & 6 & 7 \\
\hline \multicolumn{8}{|l|}{ A. I: aesthetacs } \\
\hline on segs. VI/VII & $2 / 2$ & $2 / 2$ & $2 / 2$ & $2 / 2$ & $3 / 3$ & $2 / 3$ & $2 / 2$ \\
\hline A.II: setal formula & $0 / 1 / 2 / 1 / 0 / 4 / 4$ & $0 / 1 / 2 / 1 / 0 / 4 / 4 ?$ & $0 / 0 / 2 / 1 / 1 / 4 / 4$ & $0 / 2 / 2 / 1 / 0 / 4 / 4$ & $0 / 1 / 2 / 1 / 0 / 4 / 4$ & $1 / 2 / 2 / 2 / 0 / 4 / 4$ & $0 / 0 / 2 / 2 / 1 / 0 / 4 / 4$ \\
\hline Exp.:medial seta & $\mathrm{P}$ & $P ?$ & $A$ & $\mathrm{P}$ & A & $A$ & $P$ \\
\hline Md: sexual dimorphism & $\mathrm{Y}$ & & & $\mathrm{Y}$ & $\mathrm{Y}$ & Y & $\mathrm{N}$ \\
\hline Mx.II: setal formula & -- & -- & -- & $5 / 4 / 6 / 5$ & $6 / 5 / 7 / 4$ & $6 / 4 / 6 / 5$ & $6 / 4 / 6 / 4$ \\
\hline Th VI-VII & -- & -- & -- & exp.<endp. & exp.<endp. & exp.<endp. & exp.<endp. \\
\hline Th VIII female & exp.>endp. & exp.>endp.? & -- & exp.=endp. & exp. > >endp. & exp.〉>ndp. & exp.<endp. \\
\hline \multicolumn{8}{|l|}{ Th VIII male } \\
\hline Outer protuberance & & & & small & small & small & medium \\
\hline Frontal projection & very large & large & very large & large & large & very large & large \\
\hline Bsp.: frontal crest & P (large) & P (large) & A & P (large) & P (large) & $\mathrm{P}$ (large) & $\mathrm{P}$ (medium) \\
\hline Endopod & large & large & -- & large & small & very large & large \\
\hline Exp.: length/width & 4 times & 3 times & -- & 2 times & 2 times & 3 times & 4 times \\
\hline \multicolumn{8}{|l|}{ Uropod: } \\
\hline Sympod: number spines & 4 & 4 & 4 & 4 & 4 & 4 & 3 \\
\hline Spines & similar & similar? & similar & similar & distal long & basal small & similar \\
\hline Endopod: claws & 2 & $2 ?$ & 2 & 3 & 3 & 2 & 2 \\
\hline \multicolumn{8}{|l|}{ Furca: ratio among } \\
\hline $\begin{array}{l}\text { second/first spine } \\
\text { Dorsal/first spine }\end{array}$ & $\begin{array}{l}4 \text { times longer } \\
\text { dorsal=first }\end{array}$ & $\begin{array}{l}4 \text { times longer } \\
\text { dorsal=first }\end{array}$ & $\begin{array}{l}2 \text { times longer } \\
\text { dorsal=first }\end{array}$ & $\begin{array}{l}2.5 \text { times long. } \\
\text { dorsal>first }\end{array}$ & $\begin{array}{l}4 \text { times longer } \\
\text { dorsal=first }\end{array}$ & $\begin{array}{l}2 \text { times longer } \\
\text { dorsal }>\text { first }\end{array}$ & $\begin{array}{l}2 / 3 \text { longer } \\
\text { dorsal<first }\end{array}$ \\
\hline Max. length of male & 0.65 & -- & 1.10 & 0.94 & 0.67 & 0.51 & 0.79 \\
\hline length of female & 0.75 & -- & -- & 1.03 & 1.00 & 0.50 & 0.85 \\
\hline
\end{tabular}

and third spine but thinner, a little longer than fourth spine, and 1.7 times shorter than the first, which is the longest, but not very long, attaining 2.5 times length of furca.

Etymology. The species name, vasconica, is derived from the Basque Country, northeastern Spain, where the Goikoetxe cave is located and where the new species has been found. It is the first species of Bathynellacea described from the Basque Country.

REMARKS. The new species is medium-sized within the genus (see Table 6). Its antenna has eight segments, while the other six species of the genus display only seven-segmented antenna; the first segment lacks setae but the setal formula of the rest of segments is similar to $V$. edelweiss (see Table 6) and the presence of a medial seta on the exopod occurs only in $V$. balazuci and in one of the Spanish species, $V$. edelweiss. $V$. vasconica sp. nov. is the only species of the genus that lacks sexual dimorphism on the male mandibular palp. The combination of setae on the segments of the endopod of Th. I and II is unique (see Table 7), as well as the combination of setae on the basipod of all thoracopods; within Spanish species only $V$. edelweiss has two setae as does $V$. vasconica sp. nov. on the basipod of Th. I to III, but $V$. edelweiss has also two setae on Th. IV (as in the French species) whereas $V$. vasconica sp. nov. has only one as the rest of Spanish species. The female Th VIII of $V$. vasconica sp. nov. has the exopod shorter than the endopod while $V$. edelweiss has 
Table 7.- Setal formula of endopod of Thoracopods of species of Vejdovskybathynella Serban et Leclerc, 1984. Condition of $V$. espattyensis unresolved. Number of setae on basipod in brackets.

Tabla 7.- Fórmula setal del endopodio de los toracópodos de las diferentes especies del género Vejdovskybathynella Serban et Leclerc, 1984. Carácter desconocido en la especie V. espattyensis. Entre paréntesis el número de sedas del basipodio.

\begin{tabular}{lllllll}
\hline & V. balazuci & V. leclerci & V. edelweiss & V. caroloi & V. pascalis & V. vasconica sp. nov. \\
\hline Th. I & (3) $3+0 / 1+1 / 2+0 / 4$ & (3) $3+0 / 1+1 / 2+0 / 4$ & (2) $3+0 / 2+1 / 2+0 / 4$ & (3) $2+0 / 2+1 / 2+0 / 4$ & (2) $2+0 / 2+1 / 2+0 / 4$ & $(2) 3+0 / 3+1 / 3+0 / 4$ \\
Th. II & (2) $2+0 / 1+1 / 2+0 / 3$ & (2) $2+0 / 1+1 / 2+0 / 3$ & (2) $2+0 / 2+1 / 2+0 / 4$ & (2) $2+0 / 2+1 / 2+0 / 4$ & (2) $2+0 / 2+1 / 2+0 / 4$ & $(2) 2+0 / 2+1 / 1+0 / 4$ \\
Th. III & (2) $1+0 / 0+1 / 2+0 / 3$ & (2) $2+0 / 1+1 / 2+0 / 3$ & (2) $2+0 / 2+1 / 2+0 / 4$ & (1) $2+0 / 2+1 / 2+0 / 3$ & (1) $1+0 / 2+1 / 2+0 / 4$ & $(2) 1+0 / 2+1 / 2+0 / 4$ \\
Th. IV & (2) $1+0 / 0+1 / 2+0 / 3$ & (2) $2+0 / 1+1 / 2+0 / 3$ & (2) $1+0 / 1+1 / 1+0 / 4$ & (1) $1+0 / 1+1 / 1+0 / 3$ & (1) $1+0 / 1+1 / 1+0 / 4$ & $(1) 0+0 / 1+1 / 1+0 / 4$ \\
Th. V & (1) $1+0 / 0+1 / 1+0 / 3$ & (1) $1+0 / 1+1 / 2+0 / 3$ & (1) $1+0 / 1+1 / 1+0 / 4$ & (1) $0+0 / 1+1 / 1+0 / 3$ & (1) $0+0 / 1+1 / 1+0 / 4$ & $(1) 0+0 / 0+1 / 1+0 / 3$ \\
Th. VI & (1) $0+0 / 0+0 / 0+0 / 2$ & (1) $0+0 / 0+0 / 0+0 / 2$ & (1) $1+0 / 0+1 / 0+0 / 2$ & (1) $0+0 / 0+1 / 0+0 / 2$ & $(1) 0+0 / 0+1 / 0+0 / 2$ & $(1) 0+0 / 0+1 / 0+0 / 2$ \\
Th. VII & (1) $0+0 / 0+0 / 0+0 / 2$ & (1) $0+0 / 0+0 / 0+0 / 2$ & (1) $1+0 / 0+1 / 0+0 / 2$ & (1) $0+0 / 0+1 / 0+0 / 2$ & (1) $0+0 / 0+1 / 0+0 / 2$ & $(1) 0+0 / 0+1 / 0+0 / 2$ \\
\hline
\end{tabular}

the exopod and endopod equal in size; all other species known in this genus have the exopod longer than the endopod. The size and proportion between the different lobes of the male Th. VIII is unique, with the exopod being four times as long as wide; in $V$. edelweiss and $V$. caroloi it is twice as long as wide; the frontal crest of the basipod is very small in the new species and small in $V$. edelweiss, whereas in the rest of species it is very well developed; the spur on the frontal crest is not well developed in the new species, but very developed in V. edelweiss; the endopod is large, as in the majority of species of this genus. In $V$. vasconica $\mathrm{sp}$. nov. the second segment of the pleopod has four setae as in $V$. balazuci and $V$. leclerci. The new species is the only one with three spines on the sympod of the uropod, while the rest of the species have four; nevertheless, it has two claws on the endopod as $V$. pascalis and the three French species. Another unique feature of the new species is that the first spine of the furcal rami is the longest while in the rest of species it is the second which is longest; in addition, the dorsal spine is shorther than the first three spines, whereas in the rest of species they are of similar size, or with the first one somewhat longer.

\section{Morphological discussion}

There is no doubt that the new species belongs to the genus Vejdovskybathynella, described originally from the South of France, which includes three species from France, $V$. balazuci $V$. leclerci and $V$. espattyensis Serban et Leclerc, 1984 and three from Spain, $V$. edelweiss, $V$. caroloi and $V$. pascalis.

Tables 6 and 7 show the similarities and differences between the seven species of the genus Vejdovskybathynella. In the original description of $V$. espattyensis Serban et Leclerc, 1984, only the differences with the type species $V$. balazuci Serban et Leclerc, 1984 were described, and no drawings of the majority of the body parts were provided. For this reason, there is not the same level of detail in the comparisons between species in our tables. For example, Mx. I and Mx. II are unknown in the French species.

The larger species are $V$. leclerci and $V$. edelweiss, and the smallest is $V$. pascalis; the new species is medium-sized. The three French species show more similarities between themselves than those seen between the Spanish species.

Only $V$. caroloi has three aesthetascs on segment 6 of antennule.; only $V$. vasconica sp. nov. has eight segments on antenna; only $V$. pascalis has setae on the first segment of A. II; the medial seta of the exopod of A. II is absent in $V$. leclerci, $V$. caroloi and $V$. pascalis.

The sexual dimorphism in the mandibular palp of the Md. is more evident in $V$. edelweiss and $V$. caroloi than in the other species where it is very subtle and it does not exist in the new species.

The setal formula of the endopod of Th. I-VII in the French species is mostly similar, with only slight differences in the number of setae of Th. IIIV (Table 7). The Spanish species differ in number 
Table 8.- Summary of genetic divergence (\%) for COI between different level of taxa of populations of Bathynellidae from Northern of Spain. Outgroup used: Iberobathynella imuniensis of the Parabathynellidae family.

Tabla 8.- Resumen de la divergencia genética encontrada en el gen COI entre diferentes poblaciones de la familia Bathynellidae del Norte de España, pertenecientes a varios géneros y especies. Grupo externo usado: Iberobathynella imuniensis de la familia Parabathynellidae.

\begin{tabular}{|c|c|c|c|c|c|}
\hline & Intraspecific & Intrageneric & Intergeneric & Intrafamily & Interfamily \\
\hline Bathynellidae/Parabathynellidae & & & & & $22.05-25.20$ \\
\hline Bathynellidae Spain/Bathynellidae Australia & & & & $17.72-21.85$ & \\
\hline Vejdovskybathynella/Paradoxiclamousella & & & $15.75-19.45$ & & \\
\hline Vejdovskybathynella/ Vejdovskybathynella & & 14.17-19.68 & & & \\
\hline Vejdovskybathynella edelweiss & 1.57 & & & & \\
\hline Paradoxiclamousella fideli & $0.39-7.30$ & & & & \\
\hline Vejdovskybathynella vasconica sp. nov. & 0.59 & & & & \\
\hline
\end{tabular}

of setae on all the segments of the endopod of Th. I-VII, as well as in the number of setae on the basipod of the thoracopods (Table 7); only V. edelweiss has one seta on the first segment of the endopod of Th. VI and VII. The exopod of the thoracopods is smaller than the endopod in all thoracopods in $V$. edelweiss and $V$. caroloi, whereas it is larger or almost similar in Th. I-V in $V$. pascalis and $V$. vasconica sp. nov.

In the female Th. VIII the exopod is larger than the endopod, except in $V$. edelweiss and $V$. vasconica sp. nov., where they are similar in size or shorter. Only the new species lacks setae on the coxopod.

The male Th. VIII of $V$. edelweiss and $V$. vasconica sp. nov. is more similar to $V$. balazuci and $V$. espattyensis than to the Spanish species, though they have a less-developed frontal projection and a more rectangular basipod than the French species. The male Th. VIII of V. pascalis and V. carolo $i$ have a more square aspect.

The pleopod of the new Spanish species has four setae on the second segment like two of the French species, whereas the third French species has six setae and the other Spanish species have five.

$V$. vasconica sp. nov. is the only species of the genus with three spines on the sympod of the uropod. The new species and $V$. pascalis have two claws on the endopod of the uropod like the French species; the rest of Spanish species display three claws.

$V$. edelweiss and V. pascalis have dorsal spines on the furcal rami that are longer than the first spine; in the case of the new species they are smaller and in the rest of the species they are all similar; in $V$. vasconica sp. nov. the first spine of the furcal rami is longest, whereas the second spine is longest in the rest of species of the genus and is very long in $V$. balazuci, $V$. espattyensis, and $V$. caroloi (four times longer than the first spine).

\section{Molecular Results}

\section{NuCleotide ANALYsis}

The alignment of all Bathynellacean COI gene sequences ( 15 specimens in total) resulted in a consensus length of $508 \mathrm{bp}$, of which $58 \%$ were variable. The models of sequence evolution selected for the mtDNA were GTR + I + G. No stop codons or gaps were observed in any of the translated amino acid sequences suggesting that the genuine mtDNA COI gene was sequenced. The base frequencies were as follows: $\mathrm{A}=0.29, \mathrm{C}=0.13, \mathrm{G}=0.14$ and $\mathrm{T}=$ 0.44 .

The alignment of all Bathynellacean 18S rRNA gene sequences (16 specimens) comprised 45\% variable sites; base frequencies were similar in all cases, about $25 \%(24.9 \% \mathrm{~A}, 24.2 \% \mathrm{C}$ and $\mathrm{T}$ and $26.7 \% \mathrm{G})$.

\section{Genetic Divergences}

The genetic divergence of COI is relevant at the species level, with significant results found within the different morphospecies (Camacho et al., 2011, 2012). The uncorrected sequence divergence esti- 
Table 9.- Summary of $18 \mathrm{~S}$ rRNA genetic divergence (\%) between different families, genera, populations of Bathynellacea from Spain. Outgroup used: Anaspides tasmaniae.

Tabla 9.- Resumen de la divergencia génetica (\%) encontrada en el gen 18S ARNr entre diferentes familias, géneros y poblaciones de Bathynellacea de España. Grupo externo usado: Anaspides tasmaniae.

\begin{tabular}{|c|c|c|c|c|}
\hline & Intrageneric & Intergeneric & Interfamily & Interorder \\
\hline Anaspidacea/Bathynellacea & & & & $11-44-14.98$ \\
\hline Anaspidacea/Bathynellidae & & & & $12.27-14.98$ \\
\hline Anaspidacea/Parabathynellidae & & & & $11.45-12.16$ \\
\hline Bathynellidae/Parabathynellidae & & & $7.60-12.06$ & \\
\hline Hexabathynella/Paraiberobathynella & & $6.52-6.93$ & & \\
\hline Hexabathynella/lberobathynella & & 6.12-6.94 & & \\
\hline Paraiberobathynella/lberobathynella & & $0.83-1.97$ & & \\
\hline Paraiberobathynella/Paraiberobathynella & 0.41 & & & \\
\hline Iberobathynella/lberobathynella & $0.93-2.17$ & & & \\
\hline Vejdovskybathynella/Paradoxiclamousella & & 6.84-7.97 & & \\
\hline Vejdovskybathynella/Vejdovskybathynella & $0-2.15$ & & & \\
\hline Paradoxiclamousella/Paradoxiclamousella & $0-1.41$ & & & \\
\hline
\end{tabular}

mates between the specimens and the outgroup taxa are summarized in Table 2. The genetic divergence between the outgroup used, Iberobathynella imuniensis Camacho, 1987 (Parabathynellidae) and the Bathynellidae species is $22 \%$ to $25.2 \%$. The average uncorrected sequence divergence estimates between families and genera taxa are summarized in Table 8. The sequence divergence for COI among genera was defined (Vejdovskybathynella and Paradoxiclamousella) as ranging between $15.75 \%$ to $19.45 \%$. The divergence between species of Vejdovskybathynella was similar to the distance shown between Vejdovskybathynella and Paradoxiclamousella, $14.17 \%$ to $19.68 \%$. Finally, Vejdovskybathynella caroloi showed more genetic distance with $V$. edelweiss $(18.9 \%$ to $19.7 \%)$ than with $V$. vasconica sp. nov. (16.5\% to $16.7 \%)$.

Within the same genus, the new species showed a genetic distance of $14.2 \%$ to 16.7 with respect to other species of Vejdovskybathynella, the maximum being with $V$. caroloi and the minimum with $V$. edelweiss (Table 2). The divergence of the new species with different populations of Paradoxiclamousella fideli ranged from $15.7 \%$ to $16.7 \%$, while the divergence with the only known COI sequence of an Australian species of the family Bathynellidae showed the highest genetic distance (from $18.7 \%$ to $19.3 \%$ ). The lowest genetic distance found between species was with the assigned specimen from Imunia cave (12.8\%). In the case of the specimens from Río Chico cave and Erizo rivers in the Ojo Guareña cave, genetic distances ranged from $13 \%$ to $13.6 \%$. Finally, the genetic distance between the two specimens studied of $V$. vasconica sp. nov. was only $0.6 \%$.

The uncorrected sequence divergence estimates of $18 \mathrm{~S}$ rRNA between all the specimens studied and the outgroup taxa are summarized in Table 3. The genetic divergence between the outgroup used, Anaspides tasmaniae (Thomson, 1893) and both families of the Bathynellacea ranges from $11.44 \%$ to $14.98 \%$. The average uncorrected sequence divergence estimates between families and genera, and with the outgroup taxa are summarized in Table 9. Anaspides shows more genetic divergence with the Bathynellidae than with the Parabathynellidae. Genetic divergence between genera, in both families, are normally between $6 \%$ and $8 \%$, with the exception of the distance shown between Iberobathynella and Paraiberobathynella, which is only about $2 \%$, a value more typical of intrageneric genetic divergence. The lowest distance between both families occurred between I. parasturiensis and $V$. edelweiss $(7.60 \%)$, and the highest between Pi. cf. maghrebensis and P.cf. fideli (12.06\%).

In both families, the lowest distance between two species in the same genus occurred in the Paraiberobathynella $(0.41 \%)$, and the highest between Iberobathynella burgalensis (from the North of Spain) and I. celiana (from southern Spain) 


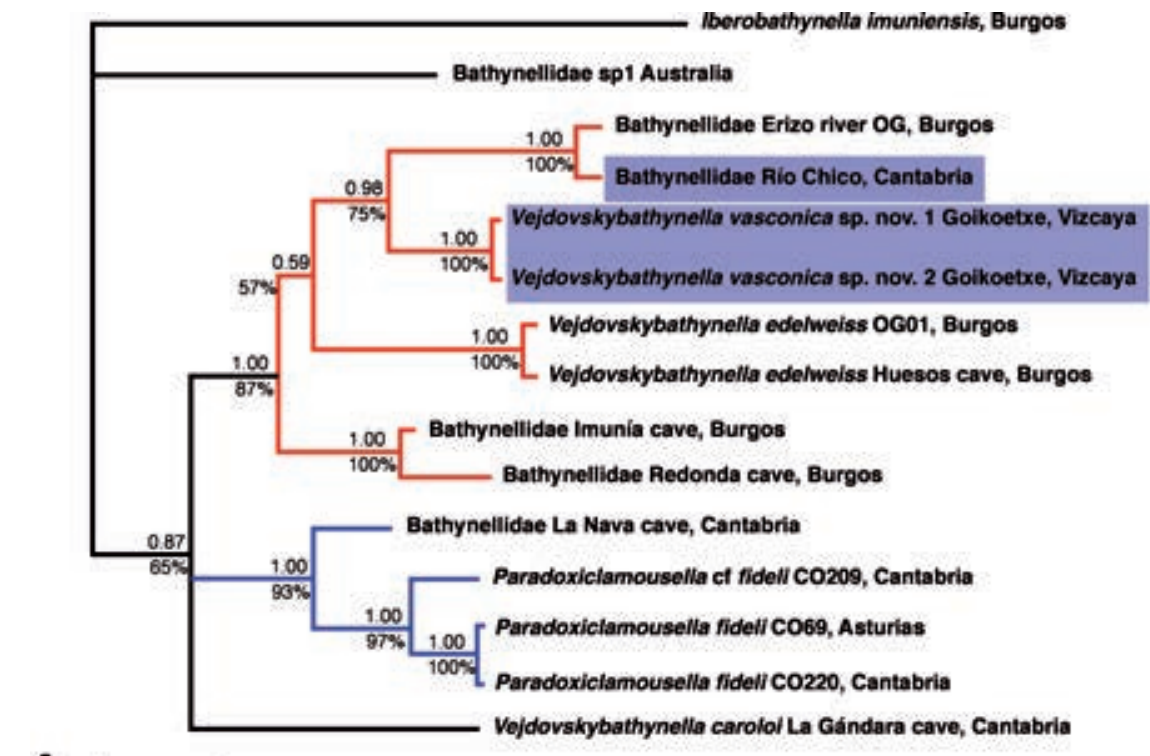

A
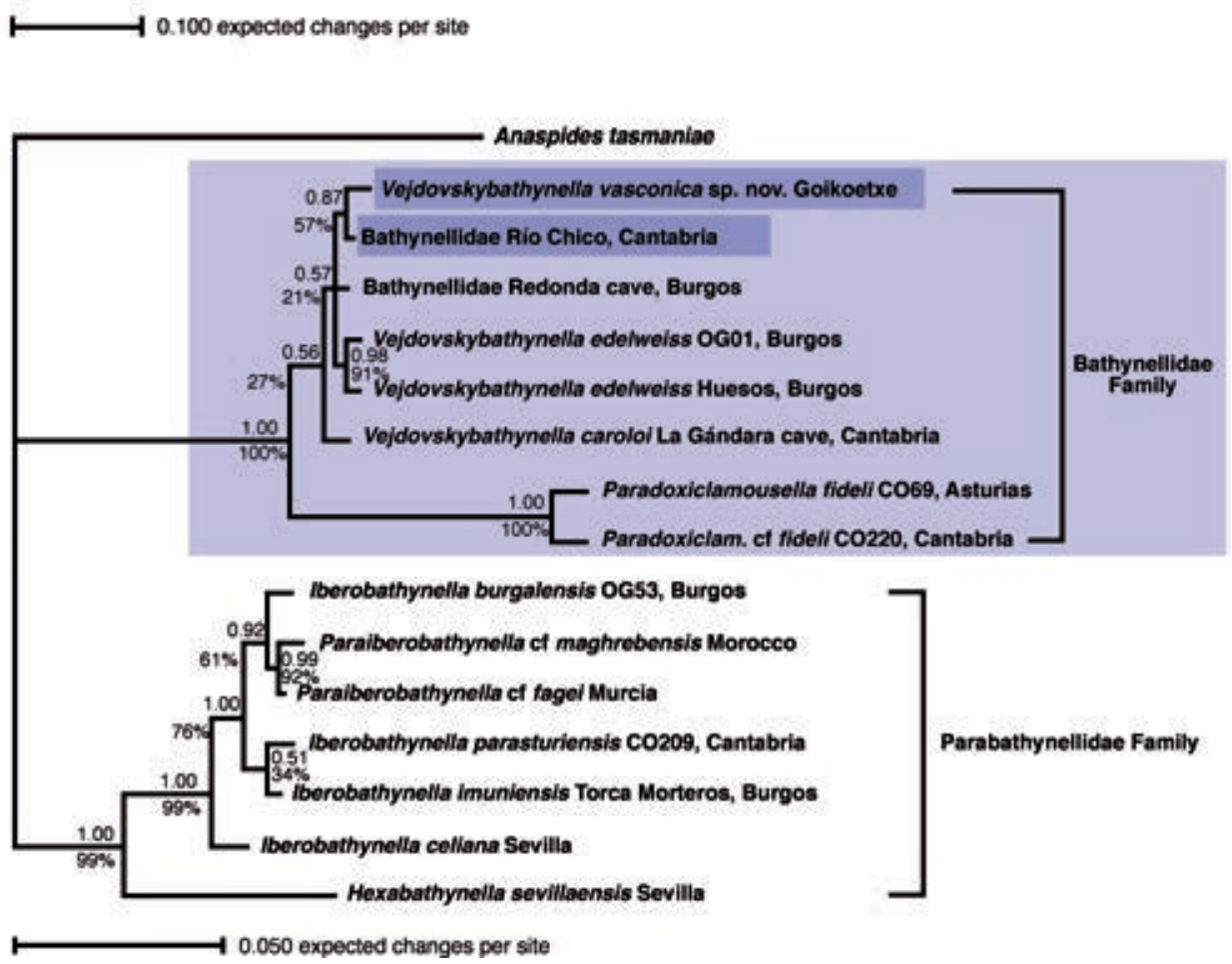

Fig. 4.- Phylogenetic reconstruction of the mitochondrial lineages (A) of Spanish Bathynellidae and the 18S rRNA data (B) of Spanish Bathynellacea. Posterior probability Bayesian consensus tree with re-estimated branch lengths using the GTR $+I+G$ model of substitution. Bayesian posterior probabilities and credibility values are shown above on corresponding nodes, and Maximum likelihood (ML) below.

Fig. 4.- Reconstrucción filogenética de linages mitocondriales (A) de la familia Bathynellidae de España y a partir de datos del 18S ARNr (B) de Bathynellacea de España. Árbol de consenso con probabilidad posterior Bayesiana, longitud de ramas reestimada usando el modelo de sustitución GTR + I + G . Los valores de probabilidad bayesiana se muestran encima de los nodos correspondientes, y la probabilidad máxima (ML) debajo. 
(2.17\%), followed by $2.15 \%$ between Vejdovskybathynella edelweiss and $V$. caroloi.

\section{Phylogenetic AnAlyses}

The results of the phylogenetic analyses (ML, Bayesian) are summarized in Fig. 4A and B. The COI mtDNA sequence data analysis produced a tree (A) in which all samples of Bathynellidae are clearly separated from Iberobathynella imuniensis (Parabathynellidae) and Bathynellidae sp1 from Australia. There are two groups supported in ML and Bayesian analyses ( $>100 \%$ Bayesian posterior probability and $93 \%$ and $87 \%$ bootstrap values). The phylogenetic reconstruction revealed that the major clades were clearly grouped in at least two different genera: Paradoxiclamousella and Vejdovskybathynella. The first robust group (93\% bootstrap) is formed by P. fideli from CO69 cave, the population of $\mathrm{CO} 209$ cave and an unassigned Bathynellidae from La Nava cave (probably belonging to Paradoxiclamousella genus). The other clade ( $87 \%$ bootstrap) is formed by the specimens of Vejdovskybathynella edelweiss (Ojo Guareña and Huesos caves), the new species (Vejdovskybathynella vasconica) and two subgroups formed by unassigned Bathynellidae from Imunia and Redonda caves and Erizo river and Río Chico caves respectively (probably belonging to Vejdovskybathynella). The species from La Gándara cave, Vejdovskybathynella caroloi, appears as the only phylogenetic incongruence in the topologies observed in the gene tree for COI. The type locality of the new species is geographically farther from Paradoxiclamousella populations than Vejdovskybathynella edelweiss and $V$. caroloi populations (see Figure 5). V. vasconica sp. nov. shows enough genetic distance with respect to V. edelweiss (about 15\%) and V. caroloi $(15.75 \%$ to $16.73 \%$ )as to be separated into a different clade (see Table 2).

The 18S rRNA sequence data analysis produced a tree (B) in which there are two groups supported in ML and Bayesian analyses $>100 \%$ Bayesian posterior probability and $99 \%$ and $100 \%$ bootstrap values). All samples of Bathynellidae are clearly separated from the Parabathynellidae. The phylogenetic reconstruction of the Parabathynellidae family revealed that the major clades clearly grouped, at least, two different genera: Hexabathynella and Iberobathynella. Paraiberobathynella appears nested within the group of Iberobathynella species, and although the bootstrap value is not very high $(61 \%)$, this indicates a small phylogenetic incongruence. The phylogenetic reconstruction of the Bathynellidae revealed that the first robust group ( $100 \%$ bootstrap) is formed by P. fideli from CO69 cave and the population of CO209 cave. The other group is formed by Vejdovskybathynella (including the new species described herein) and various unassigned specimens from several populations, but the support is somewhat weak $(27 \%)$.

\section{General discussion and conclusion}

According to Serban (2000), none of the Iberian species belong to the genus Bathynella Vejdovsky, 1882, which ranges mainly to the northeast of France and never beyond the Pyrenees (Camacho, 2007). Current knowledge suggests that other representatives of the subfamily Gallobathynellinae Serban, Coineau et Delamare Deboutteville, 1971, populate most of France and the entire Iberian Peninsula. Here we describe a new species from northern Spain belonging to Vejdosvkybathynella. This is the fourth species of this genus found in Spain, all of them being limited to the north of the Iberian Peninsula (Fig. 5).

The new species lives in groundwater of epikartic gours and pools in a Basque cave and shows very subtle morphological differences with other Vejdosvkybathynella species.

In this study we have complemented the morphological analysis with a molecular analysis to support the validity of the new species described. We present all the morphological characters needed to establish a new taxon, as required by classical taxonomy, but we also have added new characters (mtDNA and 18S rRNA sequences) obtained with molecular techniques.

The genetic divergences observed in partial COI mtDNA sequences of the new species, 14.17 to $16.73 \%$, should be enough to discriminate between congeneric species. At the moment, we still lack clear taxon definitions, and the demarcation of species using genetic divergences based on a single mitochondrial sequence is still imprecise (Meier et al., 2008). In a previous paper, we found values of divergence between 14 and 17\% for different morphospecies of the genus Vejdovskybathynella (Camacho et al., 2011, 2012), and values ranging between 15.8 and $23.6 \%$ between morphospecies 


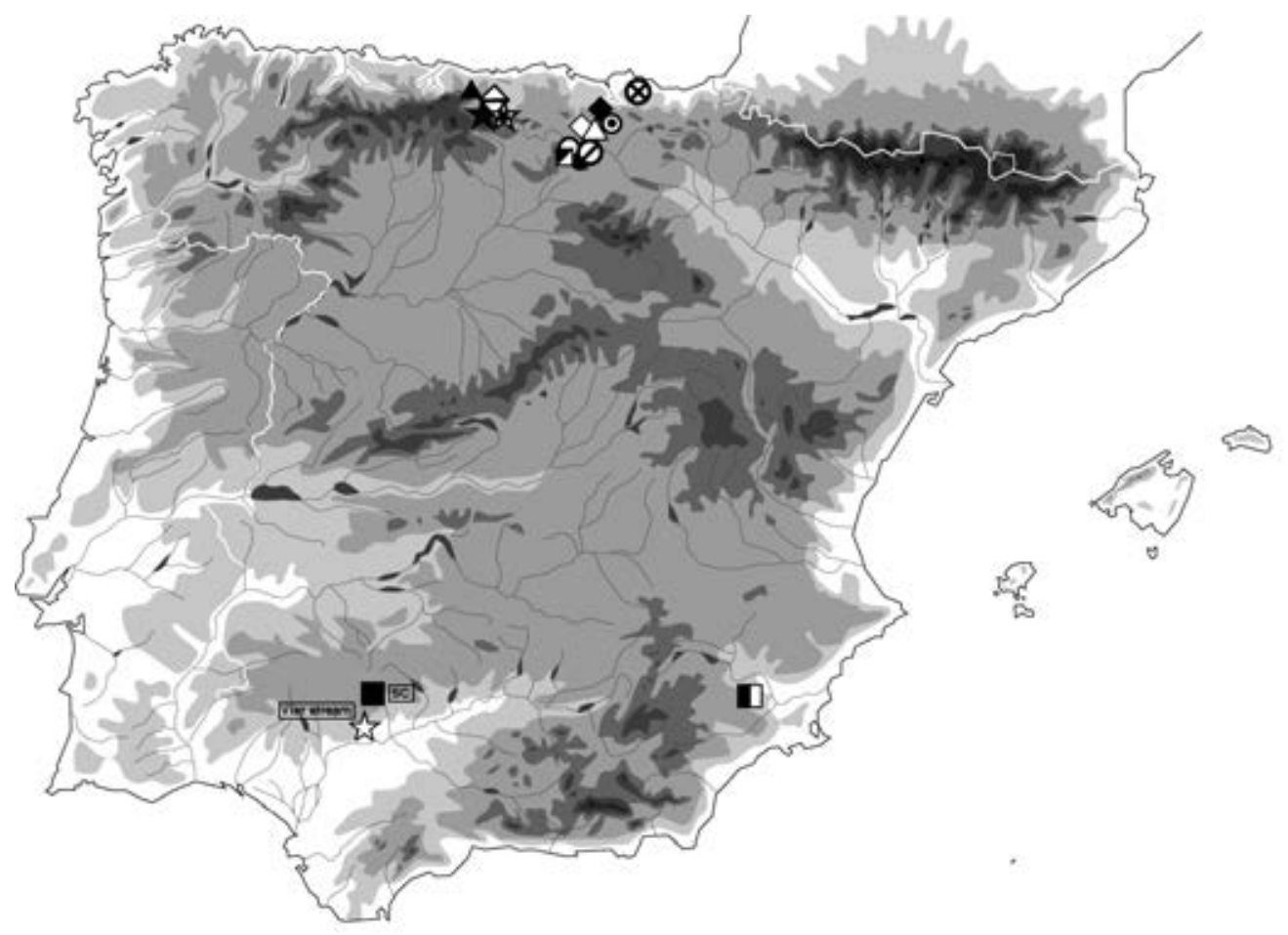

Bathynellidae

Vejdovskybathynella ede/weiss V. caroloi

V. vasconica sp. nov.

Bathynellidae Erizo river Bathynellidae Redonda cave

Bathynellidae Imunia cave

Bathynellidae Rio Chico cave

Bathynellidae La Nava cave

Paradoxiclamousella fideli

P. cf fideli
Parabathynellidae

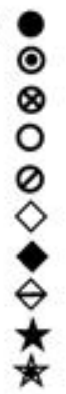

Iberobathynella burgalensis

I. imuniensis

l. celiana

I. parasturiensis

Pi. cf fagei

Hexabathynella sevillaensis

Fig. 5.- Distribution of Spanish Bathynellacean with COI and 18S rRNA sequences known.

Fig. 5.- Distribución de las especies españolas de Bathynellacea de las que se conocen secuencias de los genes COI y $18 \mathrm{~S}$ ARNr.

of Iberobathynella Schminke, 1973 divergence to be a consistent threshold for distinct (Parabathynellidae) (Camacho et al., 2012). species. Costa et al. (2007) suggested that a 17\% Nevertheless, since genetic divergence thresholds can vary among organisms, currently it is not clear what level of divergence designates a significant difference within and among lineages. Within crustaceans, Lefébure et al. (2006) investigated the relationship between morphospecies and genetically diverse species and identified $16 \%$ genetic divergence assessed different species between decapoda crustaceans. Abrams et al. (2012) found genetic divergences varying from $6.2 \%$ to $15.9 \%$ among 11 species of Brevisomabathynella Cho, Park et Ranga Reddy, 2006. The divergence between species in Atopobathynella Schminke, 1973 (Parabathynellidae) from Australia was much lar- 
ger, ranging from $15.8 \%$ to $24.6 \%$, . For the purpose of this study, the genetic divergences found and the robustness of the main clades assure us that our new species, $V$. vasconica sp. nov., is certainly valid and belongs to the genus Vejdovskybathynella. The results also show that the specimens from Erizo river and Río Chico cave probably belong to Vejdovskybathynella, and that the species of these two caves, is closer to $V$. vasconica sp. nov. than to $V$. edelweiss. In addition, the phylogenetic position established for some unassigned taxa provides a first indication of their relationship both to each other and to other species currently morphologically well identified and supported by their geographical distribution (see map of the Fig. 5).

Besides the COI sequences, partial sequences of $18 \mathrm{~S}$ rRNA (about $1000 \mathrm{bp}$ ) have been obtained in this study. This is the first time this is done in Spanish Bathynellacea, so we do not have previous data to establish comparisons. Abrams et al. (2012) obtained partial sequences (about $700 \mathrm{bp}$ ) of several species belonging to three Australian genera of Parabathynellidae, and one more sequence of one unassigned specimen of Australian Bathynellidae. They found on average $18 \mathrm{~S}$ rRNA sequence divergence among genera between $3.1 \%$ and $8.8 \%$, and an average divergence between all Australian parabathynellid species of $4 \%$. In our study, the genetic divergences observed in partial $18 \mathrm{~S}$ rRNA sequences between the new species and other Spanish Bathynellidae ranged from 1.63 to $6.12 \%$ (see Table 3). We have not included the Genbank sequences of Australian species in our data-set since the combined number of base pairs was very small to offer good results. In the phylogenetic tree obtained using only our data several small incongruences within two major clades that correspond to both families were found. For example, Iberobathynella burgalensis, I. parasturiensis and I. imuniensis appear in the same group, but Paraiberobathynella appears nested within them. In addition, the group corresponding to Vejdovskybathynella is not very well supported, despite the geographical proximity of species (see Fig. 5).

It would be necessary to obtain longer sequences of these genes, as well as to consider more genes in order to expand the molecular studies. This should be done in parallel to further morphological analyses to outline the populations composed by specimens of mixed species, of different or the same genera. The use of both classical taxono- mic tools and molecular techniques will generate more precise knowledge on the taxonomy of a group of groundwater invertebrates that is proving to be much more diverse than previously considered.

\section{Acknowledgements}

We gratefully acknowledge C. Puch, C. Prieto, G. Aranzábal, M.A. Alonso Zarazaga, D. Jaume and X. Eekhout, who helped us in different ways. This work was supported by project CGL2010-15786 MICINN.

\section{References}

Abrams, K. M., Guzik, M. T, Cooper, S. J. B., Humphreys, W. F., King, R. A., Cho, J.-L. \& Austin, A. D., 2012. What lies beneath: Molecular phylogenetics and ancestral state reconstruction of the ancient subterranean Australian Parabathynellidae (Syncarida, Crustacea). Molecular Phylogenetics and Evolution, 64: 130-164. doi: 10.1016/j.ympev.2012.03.010

Altschul, S. F., Madden, T. L., Schaeffer, A. A., Zhang, J., Zhang, Z., Miller, W. \& Lipman, D. J., 1997. Gapped BLAST and PSI-BLAST: a new generation of protein database search programs. Nucleic Acids Research, 25: 3389-3402. doi: 10.1093/nar/25.17.3389

Camacho, A. I., 2006. An annotated checklist of Syncarida (Crustacea, Malacostraca) in the world. Zootaxa, 1374: 1-54.

Camacho, A. I., 2007. The first record of the genus Vejdovskybathynella Serban and Leclerc, 1984 (Syncarida, Bathynellacea, Bathynellidae) in the Iberian Peninsula: three new species. Jounal of Natural History, 41(45-48): 2817-2841. doi: 10.1080/ 00222930701770760

Camacho, A. I., Dorda, B. A. \& Rey, I., 2011. Identifying Cryptic speciation across groudwater populations: first COI sequences of Bathynellidae (Crustacea, Syncarida). Graellsia, 67(1): 7-12. doi: 10.3989/ graellsia.2011.v67.031

Camacho, A. I., Dorda, B. A. \& Rey, I., 2012. Undisclosed taxonomic diversity of Bathynellacea (Malacostraca: Syncarida) in the Iberian Peninsula revealed by molecular data. Journal of Crustacean Biology, 32(5): 816-826. doi: 10.1163/193724012X638473

Camacho, A. I., Dorda, B. A. \& Rey, I., 2013 (in press). Old and new taxonomic tools: description of a new genus and two new species of Bathynellidae family from Spain with morphological and molecular characters. Journal of Natural History (in press)

Chenuil, A., 2006. Choosing the right molecular genetic markers for studying biodiversity:from molecular 
evolution to practical aspects. Genetica, 127: 101120. doi: 10.1007/s10709-005-2485-1

Costa, F. O., de Waard, J. R., Boutillier, J., Ratnasingham, S., Dooh, R. T., Hajibabaei, M. \& Hebert, P. D., 2007. Biological identifications through barcodes: the case of the Crustacea. Canadian Journal of Fisheries and Aquatic Sciences, 64: 272-295. doi: 10.1139/F07- 008

Felsenstein, J., 1981. Evolutionary trees from DNA sequences: a maximum likelihood approach. Journal of Molecular Evolution, 17: 368-376.

Felsenstein, J., 1985. Confidence limits on phylogenies: An approach using the bootstrap. Evolution, 39: 783791.

Felsenstein, J. \& Kishino, J. H., 1993. Is there something wrong with the bootstrap on phylogenies? A reply to Hillis and Bull. Systematic Biology, 42: 193-200. doi: $10.2307 / 2992541$

Folmer, O., Black, M., Hoeh, W., Lutz, R. \& Vrijenoek, R., 1994. DNA primers for amplification of mitochondrial cytochrome c oxidase subunit 1 from diverse metazoan invertebrates. Molecular Marine Biology and Biotechnology, 3: 294-299.

Giribet, G., Carranza, S., Baguñà, J., Riutort, M. \& Ribera, C., 1996. First molecular evidence for the existence of a Tardigrada + Arthropoda clade. Molecular Biology and Evolution, 13: 76-84.

Gu, X., Fu, Y. X. \& Li, W. H., 1995. Maximum likelihood estimation of the heterogeneity of substitution rate among nucleotide sites. Molecular Biology and Evolution, 12: 546-557.

Hillis, D. M. \& Dixon, M. T., 1991. Ribosomal DNA: Molecular Evolution and Phylogenetic Inference. The Quarterly Review of Biology, 66: 411-453.

Huelsenbeck, J. P. \& Ronquist, F., 2001. MrBayes: Bayesian inference of phylogenetic trees. Bioinformatics, 17: 754-755.

Lefébure, T., Douady, C. J., Gouy, M., Trontelj, P., Briolay, J. \& Gibert, J., 2006. Phylogeography of a subterranean amphipod reveals cryptic diversity and dynamic evolution in extreme environments. Molecular Ecology, 15: 1797-1806. doi: 10.1111/j. 1365-294X.2006.02888.x

Meier, R., Zhang, G. \& Ali, F., 2008. The use of mean instead of smallest interspecific distances exaggerates the size of the "barcoding gap" and leads to misidentification. Systematics Biology, 57: 809-813. doi: 10.1080/10635150802406343

Noodt, W. \& Galhano, M. H., 1969. Studien an Crustacea Subterranea (Isopoda, Syncarida, Copepoda) aus dem Norden Portugals. Publicaçoes do Instituto de Zoología "Dr. Augusto Nobre", 107: 9-75.

Posada, D. \& Crandall, K. A., 1998. Model test: testing the model of DNA substitution. Bioinformatics, 14: 817-818.
Ronquist, F. \& Huelsenbeck, J. P., 2003. MrBAYES 3: Bayesian phylogenetic inference under mixed models. Bioinformatics, 19: 1572-1574.

Serban, E., 1977. Sur les Bathynellidae (Podophallocarida, Bathynellacea) de l'Italie: Meridiobathynella cf. rouchi Serban, Coineau et Delamare. Travaux de l'Institut de Spèologie "Émile Racovitza", 16: 17-35.

Serban, E., 1989a. Taxa nouveaux des bathynellides d'Europe (Bathynellacea, Podophallocarida, Malacostraca). Travaux de l'Institut de Spèologie "Émile Racovitza", 28: 3-17.

Serban, E., 1989b. Le système des Gallobathynellines et sur certains rapports entre les péréiopodes 8 des Bathynellidés (Bathynellacea, Podophallocarida, Malacostraca). Miscellanea Speologica Romanica, 1: 121-168.

Serban, E., 2000. Uenobathynella n.g., Parauenobathynella n.g., Morimotobathynella n.g., Nihobathynella n.g. et Paradoxibathynella n.g., Bathynellinae du Japón (Bathynellidae, Bathynellacea, Podophallocarida). Travaux de l'Institut de Spèologie "Émile Racovitza", 36: 3-61.

Serban, E. \& Leclerc, P., 1984. Cinq taxa nouveaux des Bathynellidés de France (Bathynellacea, Podophallocarida, Malacostraca). Travaux de l'Institut de Spèologie "Émile Racovitza", 23: 7-18.

Simon, C. 1., Frati, F., Beckenbach, A., Crespi, B., Liu, H. \& Flook, P., 1994. Evolution, weighting, and phylogenetic utility of mitochondrial gene sequences and a compilation of conserved PCR primers. Annals of the Entomological Society of America, 87: 51-701

Swofford, D. L., 2002. PAUP*: Phylogeny Analysis Using Parsimony (*and other methods), version 4.0b9. Sinauer Associates Inc., Sunderland, Massachusetts.

Swofford, D. L., Olsen, G. L., Waddell, P. J. \& Hillis, D. M., 1996. Phylogenetic inference. In: D. M. Hillis, C. Moritz \& B. K. Mable (eds.). Molecular Systematics, second edition. Sinauer Associates, Sunderland, Massachussetts: 407-514.

Tamura, K., Dudley, J., Nei, M. \& Kumar, S., 2007. MEGA4: Molecular Evolutionary Genetics Analysis (MEGA) software version 4.0. Molecular Biology \& Evolution, 24: 1596-1599. doi: 10.1093/molbev/ms m092

Walsh, P., Metzger, D. \& Higuchi, R., 1991. Chelex 100 as a medium for simple extraction of DNA for PCRbased typing from forensic material. Biotechniques, 10: 506-513.

Whiting, M. F., Carpenter, J. C., Wheeler, Q. D. \& Wheeler, W. C., 1997. The Strepsiptera problem: phylogeny of the holometabolous Insect orders inferred from $18 \mathrm{~S}$ and $28 \mathrm{~S}$ ribosomal DNA sequences and morphology. Systematic Biology, 46: 1-68. doi: 10.1093/sysbio/46.1.1 
Yang, Z., 1994. Estimating the pattern of nucleotide substitution. Journal of Molecular Evolution, 39: 105111.

Zwickl, D. J., 2006. Genetic algorithm approaches for the phylogenetic analysis of large biological sequence datasets under the maximum likelihood criterion. Unpublished Ph.D. dissertation, University of Texas at Austin.
Zwickl, D. J. \& Balhoff, J., 2006. GARLIv0.954.

Aceptado / Accepted, 6-06-2013 Publicado impreso / Published in print, 30-12-2013 